\title{
Retraction Note: Interplay between cancer cells and M2 macrophages is necessary for miR- 550a-3-5p down-regulation-mediated HPV- positive OSCC progression
}

Ming-xin Cao ${ }^{1}$, Wei-long Zhang ${ }^{1}$, Xiang-hua $\mathrm{Yu}^{1}$, Jia-shun Wu ${ }^{1}$, Xin-wei Qiao ${ }^{1}$, Mei-chang Huang ${ }^{1}$, Ke Wang ${ }^{1}$, Jing-biao $\mathrm{Wu}^{1}$, Ya-Jie Tang ${ }^{2}$, Jian Jiang ${ }^{3}$, Xin-hua Liang ${ }^{1 *}$ and Ya-ling Tang ${ }^{1 *}$

Retraction Note: J Exp Clin Cancer Res 39, 102 (2020)

https://doi.org/10.1186/s13046-020-01602-1

The Editor-in-Chief has retracted this article due to data duplication in Figs. 2D, 4D and S1F, and remarkable similarities in the backgrounds of the gels presented in Fig. S1A, which have led to a loss of confidence in the presented results and the conclusions drawn in this study.

Author Ya-ling Tang has not explicitly stated whether they agree to this retraction notice. None of the remaining authors have responded to any correspondence from the editor or publisher about this retraction.
Published online: 30 September 2021

\section{Publisher's Note}

Springer Nature remains neutral with regard to jurisdictional claims in published maps and institutional affiliations.

\begin{abstract}
Author details
${ }^{1}$ State Key Laboratory of Oral Diseases \& National Clinical Research Center for Oral Diseases, West China Hospital of Stomatology, Sichuan University, No.14, Sec.3, Renminnan Road, Chengdu 610041, Sichuan, China. ${ }^{2}$ State Key Laboratory of Microbial Technology, Shandong University, Qingdao 266237, Shandong, China. ${ }^{3}$ Department of Head and Neck Surgery, Sichuan Cancer Hospital \& Institute, Sichuan Cancer Center, School of Medicine, University of Electronic Science and Technology of China, Chengdu 610041, Sichuan, China.
\end{abstract}

The original article can be found online at https://doi.org/10.1186/s13046020-01602-1.

*Correspondence: Ixh88866@scu.edu.cn; tangyaling@scu.edu.cn

1 State Key Laboratory of Oral Diseases \& National Clinical Research Center for Oral Diseases, West China Hospital of Stomatology, Sichuan University, No.14, Sec.3, Renminnan Road, Chengdu 610041, Sichuan, China

Full list of author information is available at the end of the article

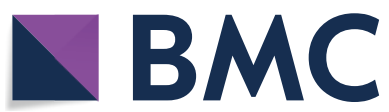

(c) The Author(s) 2021. Open Access This article is licensed under a Creative Commons Attribution 4.0 International License, which permits use, sharing, adaptation, distribution and reproduction in any medium or format, as long as you give appropriate credit to the original author(s) and the source, provide a link to the Creative Commons licence, and indicate if changes were made. The images or other third party material in this article are included in the article's Creative Commons licence, unless indicated otherwise in a credit line to the material. If material is not included in the article's Creative Commons licence and your intended use is not permitted by statutory regulation or exceeds the permitted use, you will need to obtain permission directly from the copyright holder. To view a copy of this licence, visit http://creativecommons.org/licenses/by/4.0/. The Creative Commons Public Domain Dedication waiver (http://creativecommons.org/publicdomain/zero/1.0/) applies to the data made available in this article, unless otherwise stated in a credit line to the data. 